\title{
Letter
}

\section{Using biodiversity indicators for conservation}

Indicators of biodiversity states, pressures, responses and benefits are being used at national and global levels to monitor delivery of the 2020 Aichi Targets of the Convention on Biological Diversity (CBD; Tittensor et al., 2014). Tierney et al. (2014) provided two potentially useful new options to address a gap in the indicator set on wildlife trade. We applaud these efforts and encourage the proposed development of a complementary indicator on market value and size for wild commodities. The scientific community should also help fill other priority indicator gaps, such as measures relating to ecosystem services and benefits to human wellbeing (Thapa et al., 2014; Tittensor et al., 2014). However, key challenges to data collection and use must be addressed before indicators can function as intended.

WWF recently introduced an improved system to monitor its programmes, based around indicators similar to those used to record progress against Aichi Targets (Stephenson \& O'Connor, 2014; Stephenson \& Reidhead, 2014). Based on our experiences, we identify five areas that need addressing nationally and globally to ensure adequate data are collected and biodiversity indicators sets used effectively.

Create the capacity and enabling environment Actions and resources that facilitated WWF's monitoring system included: a reporting policy with high-level management support, wellestablished project management standards, dedicated monitoring capacity in key offices, and a dedicated central team to set standards and collate and analyse data (Stephenson \& O'Connor, 2014). The CBD Parties and their partners will need to ensure similar conditions prevail, especially the development of capacity for data collection, sharing and management (Walpole et al., 2009; Tittensor et al., 2014).

Simplify data needs by harmonizing conservation measures across scales and programmes Using common indicators at multiple scales allows the same data sets and analyses (disaggregated as necessary) to be used across programmes, maximizing time and cost efficiencies. If the indicators are linked through a pressure-state-response-benefit framework they are easier to communicate and interpret (Sparks et al., 2011), especially if relevant to local users (Thapa et al., 2014). Motivation to collect and use data in WWF was enhanced when indicators reflected the needs of national or regional projects. This suggests that global indicators should be developed in ways that consider national needs and maintain local significance.

Produce data-derived products of use to decision-makers We found that reports presenting data in easy-to-use dashboards, linking reporting on performance to impact and outcome indicators, facilitated interpretation and analysis and encouraged increased use of data for adaptive management.

Build partnerships and share data Blockages exist around data sharing (e.g. Tenopir et al., 2011). WWF found that partnerships with governments and other agencies that collect or store biodiversity data are of mutual benefit. Use of global indicators will be enhanced if they are developed by diverse stakeholders with policies in place to collect and share data.

Learn and adapt The conservation community should document and share examples of monitoring, with case studies of what works well and less well.

In conclusion, we welcome the development of new biodiversity indicators but encourage them to be linked to local as well as global monitoring needs. We advocate more concerted efforts by the conservation community to build national capacity for data collection and use, and to enhance policies for data sharing.

P.J. Stephenson, Sheila O'Connor and Will ReIdHead, WWF International, Avenue du Mont Blanc, Gland, Switzerland E-mail pjstephenson@wwfint.org

JonAthan LOH Zoological Society of London, Regent's Park, London, UK

\section{References}

Sparks, T.H., Butchart, S.H.M., Balmford, A., Bennun, L., Stanwell-Smith, D., Walpole, M. et al. (2011) Linked indicator sets for addressing biodiversity loss. Oryx, 45, 411-419.

Stephenson, P.J. \& O'Connor, S. (2014) A Case Study of Conservation Monitoring Related to Aichi Targets: Experiences and Lessons from WWF. WWF International, Gland, Switzerland.

Stephenson, P.J. \& Reidhead, W. (2014) Portfolio management: measuring short- and long-term results in WWF. In Project Management Best Practices: Achieving Global Excellence, 3 rd Edition (ed. H.R. Kerzner), pp. 602-606. Wiley, New Jersey, USA.

Tenopir, C., Allard, S., Douglass, K., Aydinoglu, A.U., Wu, L., READ, E. et al. (2011) Data sharing by scientists: practices and perceptions. PLOS ONE, 6(6), e21101.

Thapa, I., Butchart, S.H., Gurung, H., Stattersfield, A.J., Thomas, D.H., \& Birch, J.C. (2014) Using information on ecosystem services in Nepal to inform biodiversity conservation and local to national decision-making. Oryx. Http://dx.doi.org/10.1017/ Soo30605314000088.

Tierney, M., Almond, R., Stanwell-Smith, D., McRae, L., Zöckler, C., Collen, B. et al. (2014) Use it or lose it: measuring trends in wild species subject to substantial use. Oryx, 48, 420-429.

Tittensor, D.P., Walpole, M., Hill, S.L., Boyce, D.G., Britten, G.L., Burgess, N.D. et al. (2014) A mid-term analysis of progress towards international biodiversity targets. Science, 346, 241-244.

Walpole, M., Almond, R.E.A., Besançon, C., Butchart, S.H.M., Campbell-Lendrum, D., Carr, G.M. et al. (2009) Tracking progress toward the 2010 biodiversity target and beyond. Science, $325,1503-1504$ 